\title{
Communication \\ Exposure to Toxoplasma gondii in Asian Elephants (Elephas maximus indicus) in Thailand
}

\author{
Ruenruetai Udonsom ${ }^{1}$, Yoshifumi Nishikawa ${ }^{2}$ (D, Ragab M. Fereig ${ }^{2,3}$, Thitirat Topisit ${ }^{4}$, \\ Natchakorn Kulkaweewut ${ }^{4}$, Supitcha Chanamrung ${ }^{4}$ and Charoonluk Jirapattharasate ${ }^{4, *}$
}

1 Department of Protozoology, Faculty of Tropical Medicine, Mahidol University, 420/6 Ratchawithi Road, Ratchathewi, Bangkok 10400, Thailand; Ruenruetai.udo@mahidol.ac.th

2 National Research Center for Protozoan Diseases, Obihiro University of Agriculture and Veterinary Medicine, Obihiro 080-8555, Hokkaido, Japan; Nisikawa@obihiro.ac.jp (Y.N.); ragabfereig2018@gmail.com (R.M.F.)

3 Department of Animal Medicine, Faculty of Veterinary Medicine, South Valley University, Qena 83523, Egypt

4 Department of Pre-clinic and Applied Animal Science, Faculty of Veterinary Science, Mahidol University, 999 Phuthamonthon sai 4 Rd, Salaya, Nakhon Pathom 73170, Thailand; Thitirat.top@student.mahidol.edu (T.T.); Natchakorn.kul@student.mahidol.edu (N.K.); Supitcha.cha@student.mahidol.edu (S.C.)

* Correspondence: Charoonluk.jir@mahidol.edu

Citation: Udonsom, R.; Nishikawa, Y.; Fereig, R.M.; Topisit, T.; Kulkaweewut, N.; Chanamrung, S. Jirapattharasate, C. Exposure to Toxoplasma gondii in Asian Elephants (Elephas maximus indicus) in Thailand. Pathogens 2022, 11, 2. https:// doi.org/10.3390/pathogens 11010002 Academic Editor: Stefania Perrucci

Received: 23 November 2021 Accepted: 20 December 2021 Published: 21 December 2021

Publisher's Note: MDPI stays neutral with regard to jurisdictional claims in published maps and institutional affiliations.

Copyright: (C) 2021 by the authors. Licensee MDPI, Basel, Switzerland. This article is an open access article distributed under the terms and conditions of the Creative Commons Attribution (CC BY) license (https:// creativecommons.org/licenses/by/ $4.0 /)$.

\begin{abstract}
Toxoplasma gondii is the causative agent of toxoplasmosis in humans and various animal species worldwide. In Thailand, seroprevalence studies on T. gondii have focused on domestic animals, and information on infections in Asian elephants (Elephas maximus indicus) is scarce. This study was conducted to determine the seroprevalence of T. gondii infection in archival sera collected from 268 elephants living in Thailand. The serum samples were analyzed for anti-T. gondii immunoglobulin $\mathrm{G}$ antibodies using the latex agglutination test (LAT) and indirect enzyme-linked immunosorbent assay (iELISA) based on T. gondii lysate antigen (TLA-iELISA) and recombinant T. gondii dense granular antigen 8 protein (TgGRA8-iELISA). The prevalence of antibodies against T. gondii was $45.1 \%(121 / 268), 40.7 \%$ (109/268), and 44.4\% (119/268) using LAT, TLA-iELISA, and TgGRA8-iELISA, respectively. Young elephants had a higher seropositivity rate than elephants aged $>40$ years (odds ratio $=6.6 ; p<0.001 ; 95 \%$ confidence interval: 2.9-15.4). When LAT was used as the reference, TLA-iELISA and TgGRA8-iELISA showed a substantial $(\kappa=0.69)$ and moderate $(\kappa=0.42)$ agreement, respectively. Although our findings suggest the widespread exposure of Asian elephants to T. gondii in Thailand, the source of infection was not investigated. Therefore, investigation of the predisposing factors associated with toxoplasmosis is necessary to identify the potential risk factors for infection.
\end{abstract}

Keywords: elephants; indirect enzyme-linked immunosorbent assay; latex agglutination test; recombinant GRA8 protein; T. gondii lysate antigens; serology; Thailand

\section{Introduction}

Toxoplasma gondii is an obligate apicomplexan parasite that is widely prevalent in most warm-blooded animals, including humans [1,2]. The definitive hosts are domestic and wild felids, which excrete environmentally robust oocysts in their feces [3]. Intermediate hosts are infected via the fecal-oral route through the ingestion of food, water, or soil contaminated with sporulated oocysts, by consuming tissue cysts, or by congenital transmission [4].

Toxoplasma sp. infections have been reported in both humans and domestic animals in Thailand. The prevalence of anti-T. gondii antibodies in Thai people is 3.1-53.7\% [5-8]. T. gondii antibodies have been detected in cats [9-11], dogs [9,12], cattle [13-15], chickens [16], and goats $[17,18]$. The seroprevalence in captive wild felids in Thailand was reported as $15.4-42.8 \%[19,20]$. Toxoplasmosis in herbivores including elephants might be caused by ingesting food or water contaminated with sporulated oocysts. Furthermore, the infected herbivorous matter indicates environmental contamination with T. gondii 
oocysts [21]. The infection of the parasite in elephants can be used to monitor disease circulation and infection risks for human or wild populations. However, information about the prevalence of T. gondii infection in Asian elephants (Elephas maximus indicus) in Thailand is scarce.

Serological assays are essential for the detection of T. gondii infection in humans and animals [22]. Various techniques have been employed to screen for specific antibodies against $T$. gondii, such as the modified agglutination test (MAT), latex agglutination test (LAT), and indirect fluorescent antibody test (IFAT). Furthermore, an enzyme-linked immunosorbent assay (ELISA) based on soluble T. gondii lysate antigens (TLAs) has been used to detect T. gondii-specific antibodies in animals [23-26]. Recently, recombinant antigenic proteins of T. gondii have been widely used for serodiagnosis of toxoplasmosis in various animal species [27]. Several target antigens of T. gondii have been evaluated and applied in serological tests, such as the surface antigen, microneme antigen, rhoptry antigen, and dense granule antigen (GRA) tests. Antigens from the GRA group, such as GRA5, GRA6, GRA7, and GRA8, have demonstrated diagnostic potential for the serological detection of animal toxoplasmosis [27].

This study aimed to investigate the seroprevalence of T. gondii infection in Asian elephants living in Thailand using a commercial test kit and compared the results with those obtained using indirect ELISA (iELISA) based on TLA and a recombinant protein of T. gondii dense granular antigen 8 (TgGRA8).

\section{Results}

The seroprevalence of IgG antibodies against T. gondii in the elephants in various parts of Thailand is presented in Table 1 . Antibodies against T. gondii were detected in the sera of 121 (45.1\%), 109 (40.7\%), and 119 (44.4\%) of 268 elephants by LAT, TLA-iELISA, and TgGRA8-iELISA, respectively. The antibody titers determined by LAT were 1:64, 1:128, $1: 256,1: 512,1: 1024$, and 1:2048 in 22, 36, 21, 27, 8, and 7 elephants, respectively. Significant differences were observed in the seroprevalence of $T$. gondii among the age groups. The prevalence of $T$. gondii infection in elephants aged $>40$ years was significantly lower than that in those aged $21-40$ years $(p=0.002)$ and those aged $1-20$ years $(p<0.001)$. There was no significant association between sex and T. gondii seroprevalence (Table 2).

Table 1. Seroprevalence of T. gondii antibody in Asian elephant sera by LAT, TLA-iELISA, and TgGRA8-iELISA.

\begin{tabular}{|c|c|c|c|c|c|c|}
\hline \multirow[t]{2}{*}{ Year of Sampling } & \multirow[t]{2}{*}{ Region } & \multirow[t]{2}{*}{ Province } & \multirow[t]{2}{*}{ No. of Elephants Tested } & \multicolumn{3}{|c|}{ Seropositivity of $T \cdot$ gondii-Specific IgG Antibodies } \\
\hline & & & & LAT (Titer $\geq 1: 64$ ) & TLA & TgGRA8 \\
\hline \multirow{14}{*}{2009} & North & Mae Hong Sorn & 6 & 4 & 4 & 1 \\
\hline & Western & Tak & 44 & 23 & 28 & 18 \\
\hline & Central & Sukhothai & 6 & 3 & 2 & 2 \\
\hline & & Pathum Thani & 4 & 1 & 1 & 1 \\
\hline & Northeast & Surin & 1 & 1 & 0 & 0 \\
\hline & South & Chumphon & 4 & 2 & 2 & 0 \\
\hline & & Krabi & 10 & 0 & 0 & 3 \\
\hline & & Nakhon $\mathrm{Si}$ Thammarat & 24 & 16 & 8 & 13 \\
\hline & & Phangnga & 4 & 3 & 4 & 3 \\
\hline & & Patthalung & 2 & 0 & 0 & 1 \\
\hline & & Ranong & 4 & 2 & 0 & 2 \\
\hline & & Satun & 1 & 0 & 0 & 0 \\
\hline & & Surat Thani & 12 & 2 & 1 & 3 \\
\hline & & Trang & 23 & 7 & 8 & 7 \\
\hline \multirow{4}{*}{2010} & Central & Ayutthaya & 9 & 4 & 4 & 5 \\
\hline & South & Krabi & 1 & 0 & 0 & 0 \\
\hline & & Phuket & 12 & 9 & 7 & 9 \\
\hline & & Surat Thani & 10 & 4 & 2 & 4 \\
\hline \multirow{3}{*}{2011} & East & Chonburi & 5 & 2 & 3 & 2 \\
\hline & Northeast & Surin & 6 & 1 & 1 & 2 \\
\hline & Western & Prachaup Kirikhan & 2 & 0 & 0 & 2 \\
\hline \multirow[b]{2}{*}{2013} & Northeast & Surin & 1 & 0 & 0 & 1 \\
\hline & Western & Kanchanaburi & 60 & 31 & 28 & 35 \\
\hline \multirow{3}{*}{2020} & Central & Nakhon Pathom & 9 & 5 & 5 & 5 \\
\hline & Western & Kanchanaburi & 8 & 1 & 1 & 0 \\
\hline & & Total & 268 & $121(45.1 \%)$ & $109(40.7 \%)$ & $119(44.4 \%)$ \\
\hline
\end{tabular}

IgG: Immunoglobulin G; LAT: Latex agglutination test; TLA: T. gondii total lysate antigen; TgGRA8 = T. gondii dense granular antigen 8 . 
Table 2. Seroprevalence of T. gondii antibody (LAT; titer $\geq 64$ ) in Asian elephant sera by sex and age-group.

\begin{tabular}{|c|c|c|c|c|c|}
\hline Variable & Total Tested & $\begin{array}{c}\text { LAT Positive } \\
(\%)\end{array}$ & OR $(95 \%$ CI $)$ & $\begin{array}{c}p \text {-Value } \\
(<0.05)\end{array}$ & $\begin{array}{c}\text { Year of Sampling } \\
\text { (No. of Positive } \\
\text { Samples/Total Tested) }\end{array}$ \\
\hline \multicolumn{6}{|l|}{ Sex } \\
\hline Female & 188 & $88(46.8 \%)$ & $0.8(0.5-1.4)$ & 0.40 & $\begin{array}{c}2009(38 / 90), 2010(14 / 24), \\
2011(2 / 13), 2013(29 / 47), \\
2020(5 / 14) \\
2009(26 / 55), 2010(3 / 8), \\
2011(1 / 1), 2013(2 / 13), 2020 \\
(1 / 3)\end{array}$ \\
\hline \multicolumn{6}{|l|}{ Age } \\
\hline $1-20$ years & 62 & $42(68.9 \%)$ & $6.6(2.9-15.4)$ & $<0.001$ & $\begin{array}{l}2009(12 / 21), 2010(4 / 5) \\
2013(25 / 34), 2020(1 / 2)\end{array}$ \\
\hline $21-40$ years & 96 & $48(50 \%)$ & $3.2(1.5-6.8)$ & 0.002 & $\begin{array}{c}2009(39 / 73), 2010(1 / 1) \\
2013(4 / 13), 2020(4 / 9)\end{array}$ \\
\hline$>40$ years & 50 & $12(24 \%)$ & Ref & & $\begin{array}{c}2009 \text { (8/30), } 2010(1 / 1), 2013 \\
(2 / 13), 2020(1 / 6)\end{array}$ \\
\hline Unknown age & 60 & $19(31.7 \%)$ & & & \\
\hline
\end{tabular}

LAT: Latex agglutination test; Ref: Reference category; OR: odds ratio; CI: confidence interval.

Evaluation of the agreement between the tests revealed that TLA-iELISA had slightly higher sensitivity (78.5\%) and specificity $(90.4 \%)$ than TgGRA8-iELISA $(67.7 \%$ and $74.8 \%$, respectively). The kappa value between LAT and TLA-iELISA was 0.69 (substantial agreement) and between LAT and TgGRA8-iELISA was 0.42 (moderate agreement) (Table 3).

Table 3. Comparison of TLA-iELISA and TgGRA8-iELISA to examine T. gondii antibodies in Asian elephants using LAT as a reference test.

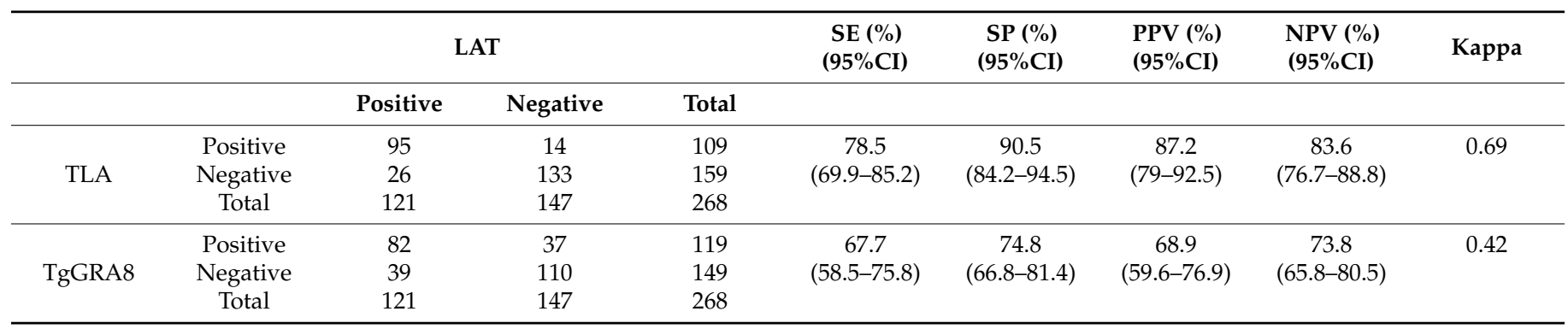

SE: sensitivity, SP: specificity, PPV: positive predictive value, NPV: negative predictive value, CI: confidence interval, Kappa agreement value.

\section{Discussion}

The seroprevalence of T. gondii in domestic and wild animals in Thailand has been investigated in the past [5-20]. However, there are few reports on T. gondii infection in elephants. In this study, the seropositivity rate for T. gondii in elephants in captivity was $>40 \%$, which was higher than previously reported seropositivity rates in Asian elephants in Thailand, which were reported as 13\% [28] and 25.6\% [29] by LAT. Because the lifespan of elephants is similar to that of humans, the likelihood of T. gondii infection is higher than that in other animals. Moreover, some elephant owners release them to explore and forage for food in nearby forests [30], where they come into contact with plants contaminated with oocysts excreted by wild felids or domestic cats. Thus, a long-term study and risk factor association of T. gondii infection in elephants in Thailand is warranted.

We did not find a difference in T. gondii seropositivity between female and male elephants, which is consistent with the findings of a previous report that both male and female elephants were equally exposed to T. gondii infection [28]. The highest seroprevalence 
of T. gondii was detected in elephants aged 1-20 years and 21-40 years, which is similar to a previous report of high T. gondii seroprevalence in adult elephants [28]. However, our results showed a low prevalence of infection in elephants aged $>40$ years. This could be due to a possible bias and the high number of elephants of unknown age $(60 / 268$, $22.4 \%$ ) in our study cohort. Because no data on congenital toxoplasmosis in elephants are available, further studies on the clinical manifestations of $T$. gondii infection in elephants should be performed.

We used LAT, TLA-iELISA, and TgGRA8-iELISA to detect $T$. gondii infection in elephant sera. Although LAT exhibited low sensitivity compared with MAT, it is widely used as a reference test for the seroprevalence of toxoplasmosis in various animal species, including elephants $[28,29,31-33]$. ELISA is a common serological test that can be easily performed on a large scale, and many commercial kits are available to detect specific immunoglobulins produced in response to $T$. gondii infection. The conventional TLA-iELISA test shows a high degree of agreement with MAT, IFAT, or LAT for detecting antibodies against $T$. gondii in both humans and animals $[25,34]$. In the present study, TLA-iELISA demonstrated high sensitivity $(78.5 \%)$ and specificity $(90.4 \%)$, and the kappa value indicated a substantial agreement with LAT $(\mathrm{K}=0.69)$ for the detection of $T$. gondii infection in elephant sera. This indicates that TLA-iELISA could be an alternative serological test for $T$. gondii infection in elephants and other wild animals. Recombinant antigens are considered alternative diagnostic antigens to native antigens and have been used to improve the serodiagnosis of T. gondii [27]. Recombinant TgGRA8 antigen has been used in ELISA to detect toxoplasmosis in both humans and animals. High sensitivity and specificity for the detection of T. gondii have been reported using TgGRA8-iELISA in humans [35], goats [36], and domestic turkeys [37]. This is the first report of using recombinant protein TgGRA8 as a coating antigen to detect antibodies against $T$. gondii in elephants. The kappa value between LAT and TgGRA8-iELISA revealed a moderate agreement $(\kappa=0.42)$, with low sensitivity and specificity. Recently, multi-epitope or chimeric antigens have been used as an alternative approach to address the need for standardizing and increasing the sensitivity and specificity of serodiagnostic tests for animal toxoplasmosis $[25,26,38]$. Therefore, the application of a single recombinant protein or a mixture of recombinant proteins in an ELISA test to diagnose T. gondii infection in elephants needs to be developed and evaluated.

The long-term storage of serum affects the stability of several biochemical components and immunoglobulins in human and animal sera [39-41]. This could be impacted on the serological tests in our study because most of serum samples were stored for a long time. However, one study revealed that IgG antibodies against $T$. gondii in human sera can be reliably measured for 10 years of storage at $-20^{\circ} \mathrm{C}$ with no modification of interpretation of toxoplasmosis serologies [41]. To clarify whether long-term storage of such animal sera has an influence on the serological testing of $T$. gondii infection, further study will be necessary.

In conclusion, T. gondii infection is fairly common in Asian elephants in Thailand. The prevalence of the infection found in wild animals in Thailand could be of public health and conservation concern. Furthermore, the Asian elephants can be used as sentinels to monitor the potential contamination in the environment with T. gondii. However, updated information on the seroprevalence of this infection in elephants and a risk factor analysis should be performed to determine the actual situation and to identify the infection source and possible transmission routes.

\section{Materials and Methods}

\subsection{Animal Samples}

Archival elephant sera $(n=268)$ in this study were obtained from the project on animal DNA fingerprints in a cooperation between the Asian Elephant Foundation of Thailand and the Monitoring and Surveillance Center for Zoonotic Diseases in Wildlife and Exotic Animals, Faulty of Veterinary Science, Mahidol University. The serum samples were collected in various provinces of Thailand from 2009 to 2013 and in 2020 (Figure 1). For this study, the sample was divided into three aliquot parts for the serological tests and frozen 
at $-30^{\circ} \mathrm{C}$. Data were recorded for each animal and included the sampling area, sampling date, sex, and age.

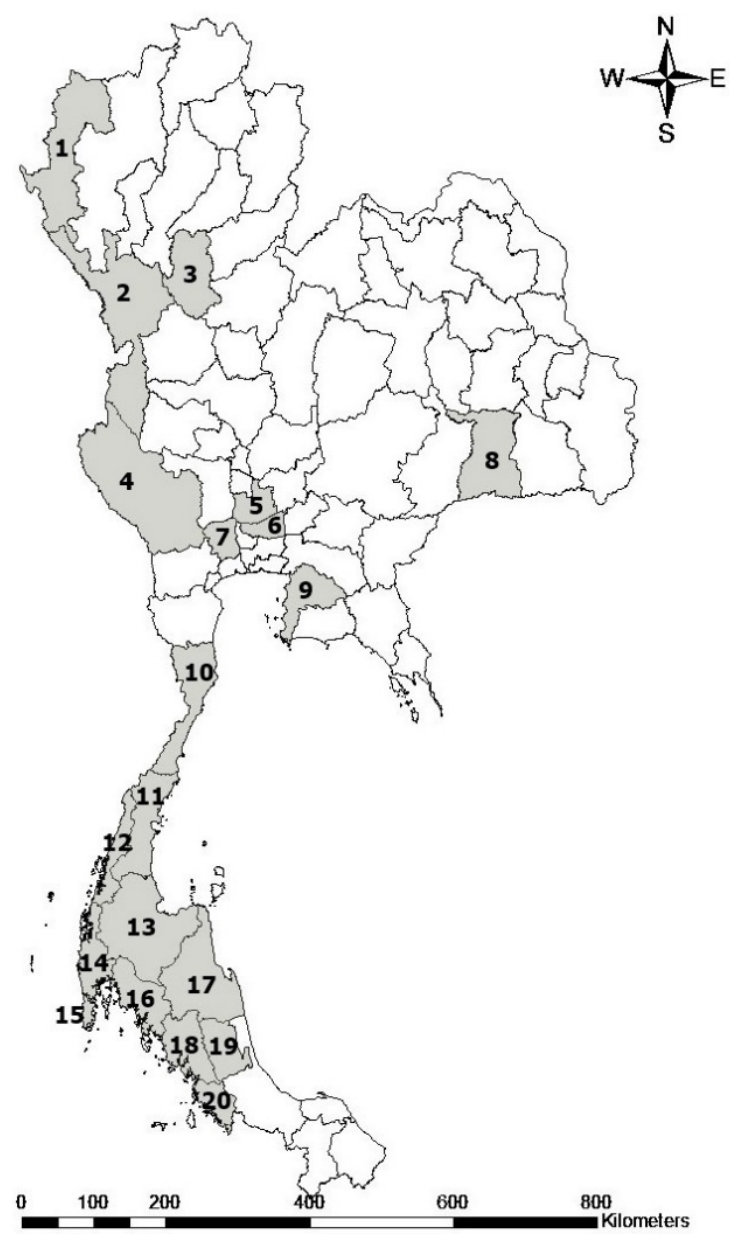

Figure 1. Geographic distribution of the sampling sites in Thailand used in this study. Dark-colored areas with different numbers indicate the investigated provinces. 1. Mae Hong Sorn, 2. Tak, 3. Sukhothai 4. Kanchanaburi, 5. Ayutthaya, 6. Pathum Thani, 7. Nakhon Pathom, 8. Surin, 9. Chonburi, 10. Prachaup Kirikhan, 11. Chumphon, 12. Ranong, 13. Surat Thani, 14. Phangnga, 15. Phuket, 16. Krabi, 17. Nakhon Si Thammarat, 18. Trang, 19. Phatthalung, 20. Satun.

\subsection{Preparation of T. gondii GRA8 Antigen}

Purified recombinant T. gondii dense granular antigen 8 (TgGRA8) was prepared as described previously [40]. Briefly, TgGRA8 (582 bp) was amplified using polymerase chain reaction and then ligated into a pET-21a vector using NdeI and XhoI as the cloning sites (General Biosystems, Durham, NC, USA) that were transfected into Escherichia coli strain Rosetta (DE3) cells. TgGRA8 protein production was induced using isopropyl- $\beta$-Dthiogalactopyranoside to a final concentration of $1 \mathrm{mM}$ with mild shaking at $20^{\circ} \mathrm{C}$ overnight. Next, the cells were centrifuged at $4400 \times g$ for $20 \mathrm{~min}$ at $4{ }^{\circ} \mathrm{C}$, and the resultant bacterial pellet was resuspended in $20 \mathrm{~mL}$ of prechilled lysis buffer. Then, the cells were disrupted by sonication on ice for $10 \mathrm{~min}$. The total proteins in the soluble fraction were subjected to affinity purification using an anti-DYKDDDDK G1 affinity resin (GenScript, Piscataway, NJ, USA) according to the manufacturer's protocols. The purity and quantity of the proteins were checked using sodium dodecyl sulfate-polyacrylamide gel electrophoresis analysis. The protein concentration was measured using the BSA assay (Pierce Biotechnology, Inc., Rockford, IL, USA). 


\subsection{Preparation of Toxoplasma Lysate Antigen}

Tachyzoites of the T. gondii RH strain were cultivated in a monolayer of Vero cells (African green monkey kidney cells) with Dulbecco's Modified Eagle's Medium (GIBCO, Grand Island, NY, USA) supplemented with 10\% heat-inactivated fetal bovine serum. The pellets were harvested and washed twice in phosphate-buffered saline (PBS), followed by three freeze-thaw cycles, based on the standard procedure. The protein concentration in the TLA preparation was measured using Bradford reagent (Sigma-Aldrich, St. Louis, MO, USA) according to the manufacturer's recommendations, and the proteins were stored at $-20{ }^{\circ} \mathrm{C}$ until use.

\subsection{Latex Agglutination Test}

We tested the elephant sera for T. gondii infection using a MAST Toxoreagent LAT (Mast Group, Liverpool, UK), according to the manufacturer's instructions. Samples were considered positive when agglutination was observed at a dilution of $\geq 1: 64$ [29].

\subsection{IgG Indirect ELISA (iELISA)}

iELISA was performed to detect $T$. gondii infection according to a previously described procedure [39], with slight modifications. Optimal dilutions were established using checkerboard titrations with dilutions of coating antigen and sera. The ELISA plates (Nunc, Roskilde, Denmark) were coated with $0.1 \mathrm{~mL}$ of TLA or TgGRA8 $(1 \mu \mathrm{g} / \mathrm{mL})$ diluted in a coating buffer (50 mM carbonate, $\mathrm{pH} 9.6)$ and were incubated at $4{ }^{\circ} \mathrm{C}$ overnight. Then, the plates were rinsed five times with PBS containing 0.05\% Tween 20 (PBS-T), and nonspecific immune sites were blocked with 5\% PBS-skimmed milk (PBS-SM) for $1 \mathrm{~h}$ at $37{ }^{\circ} \mathrm{C}$. After washing with PBS-T, the control and sample sera were diluted to 1:100 in PBS-SM, and 100 $\mu \mathrm{L}$ of this mixture was added to each well in duplicate. After incubation at $37^{\circ} \mathrm{C}$ for $1 \mathrm{~h}$, the plates were washed and incubated with $100 \mu \mathrm{L}$ of horseradish peroxidase-conjugated recombinant protein A/G (1:10,000 dilution; Thermo Fisher Scientific, Rockford, IL, USA), previously reported to bind elephant $\operatorname{IgG}[42,43]$, at $37^{\circ} \mathrm{C}$ for $1 \mathrm{~h}$. Next, the peroxidase activity was determined by adding $100 \mu \mathrm{L}$ of 3,3',5,5'-tetramethylbenzidine (Invitrogen, Carlsbad, CA, USA), and the reaction was stopped by adding $100 \mu \mathrm{L}$ of $1 \mathrm{~N}$ of $\mathrm{HCl}$. The optical density (OD) was measured at a wavelength of $450 \mathrm{~nm}$ using an ELx808 ELISA microplate reader (Bio Tec Instruments, VT, USA). Positive and negative serum controls were confirmed using MAST Toxoreagent, a commercial LAT (Liverpool, UK), and were included in all plates. Serum samples were considered positive when the average OD $>$ (OD mean [from the negative control sera] + 3 standard deviations from the negative control sera)].

\subsection{Statistical Analyses}

Data were analyzed using SPSS version 26.0 for Windows (IBM Corp., Armonk, NY, USA). The seroprevalence was calculated based on the ratio of positive results to the total number of tested animals. The association between T. gondii seropositive individuals and risk factors (age and sex) was analyzed using the chi-square test. A $p$ value of $<0.05$ was considered statistically significant. The kappa values, specificity, sensitivity, and 95\% confidence intervals were calculated using VassarStats (www.vassarstats.net (accessed on 25 , October 2021)). The strength of agreement was graded according to the kappa values as fair (0.21-0.40), moderate (0.41-0.60), or substantial (0.61-0.80).

Author Contributions: Conceptualization, C.J.; methodology, R.U., N.K., T.T. and S.C.; formal analysis, C.J.; resources, R.U., R.M.F. and Y.N.; supervision, Y.N.; writing-original draft preparation, R.U. and C.J.; writing-review and editing, R.U. and C.J. All authors have read and agreed to the published version of the manuscript.

Funding: This study was supported by the student project 2020, Faculty of Veterinary Science, Mahidol University, Thailand. 
Institutional Review Board Statement: The use of archival elephant sera in this study was approved by the Ethics and Animal Care and Use Committee of the Faculty of Veterinary Science, Mahidol University, Thailand (permit number: MUVS-2020-06-21).

Informed Consent Statement: Not applicable.

Data Availability Statement: Not applicable.

Acknowledgments: We would like to thank the Monitoring and Surveillance Center for zoonotic diseases in Wildlife and Exotic Animals, Faculty of Veterinary Science, Mahidol University and Nae Tanpradit for providing archival elephant sera. The authors thanks Phirom Prompiram for technical assistance.

Conflicts of Interest: The authors declare no conflict of interest.

\section{References}

1. Montoya, J.G.; Liesenfeld, O. Toxoplasmosis. Lancet 2004, 363, 1965-1976. [CrossRef]

2. Stelzer, S.; Basso, W.; Benavides Silván, J.; Ortega-Mora, L.M.; Maksimov, P.; Gethmann, J.; Conraths, F.J.; Schares, G. Toxoplasma gondii infection and toxoplasmosis in farm animals: Risk factors and economic impact. Food Waterborne Parasitol. 2019, 15, e00037. [CrossRef] [PubMed]

3. Zulpo, D.L.; Sammi, A.S.; dos Santos, J.R.; Sass, J.P.; Martins, T.A.; Minutti, A.F.; Cardim, S.T.; de Barros, L.D.; Navarro, I.T.; Garcia, J.L. Toxoplasma gondii: A study of oocyst re-shedding in domestic cats. Vet. Parasitol. 2018, 249, 17-20. [CrossRef] [PubMed]

4. Dubey, J.P. History of the discovery of the life cycle of Toxoplasma gondii. Int. J. Parasitol. 2009, 39, 877-882. [CrossRef] [PubMed]

5. Maruyama, S.; Boonmar, S.; Morita, Y.; Sakai, T.; Tanaka, S.; Yamaguchi, F.; Kabeya, H.; Katsube, Y. Seroprevalence of Bartonella henselae and Toxoplasma gondii among healthy individuals in Thailand. J. Vet. Med. Sci. 2000, 62, 635-637. [CrossRef] [PubMed]

6. Wanachiwanawin, D.; Sutthent, R.; Chokephaib, U.K.; Mahakittikun, V.; Ongrotchanakun, J.; Monkong, N. Toxoplasma gondii antibodies in HIV and non-HIV infected Thai pregnant women. Asian Pac. J. Allergy Immunol. 2001, 19, $291-293$.

7. Nissapatorn, V.; Noor Azmi, M.A.; Cho, S.M.; Fong, M.Y.; Init, I.; Rohela, M.; Khairul Anuar, A.; Quek, K.F.; Latt, H.M. Toxoplasmosis: Prevalence and risk factors. J. Obstet. Gynaecol. Res. 2003, 23, 618-624. [CrossRef]

8. Sukthana, Y.; Kaewkungwal, J.; Jantanavivat, C.; Lekkla, A.; Chiabchalard, R.; Aumarm, W. Toxoplasma gondii antibody in Thai cats and their owners. Southeast Asian J. Trop. Med. Public Health 2003, 34, 733-738. [PubMed]

9. Jittapalapong, S.; Nimsupan, B.; Pinyopanuwat, N.; Chimnoi, W.; Kabeya, H.; Maruyama, S. Seroprevalence of Toxoplasma gondii antibodies in stray cats and dogs in the Bangkok Metropolitan areas, Thailand. Vet. Parasitol. 2007, 145, 138-141. [CrossRef]

10. Jittapalapong, S.; Inpankaew, T.; Pinyopanuwat, N.; Chimnoi, W.; Kengradomkij, C.; Wongnarkpet, S.; Maruyama, S.; Lekkla, A.; Sukthana, Y. Epidemiology of Toxoplasma gondii infection of stray cats in Bangkok, Thailand. Southeast Asian J. Trop. Med. Public Health 2010, 41, 13-18.

11. Udonsom, R.; Buddhirongawatr, R.; Nishikawa, Y.; Fereig, R.M.; Jirapattharasate, C. Toxoplasma gondii prevalence and risk factors in owned domestic cats from Nakhon Pathom Province, Thailand. Vet. Integr. Sci. 2021, 19, 557-566. [CrossRef]

12. Huertas-López, A.; Sukhumavasi, W.; Álvarez-García, G.; Martínez-Subiela, S.; Cano-Terriza, D.; Almería, S.; Dubey, J.P.; García-Bocanegra, I.; Cerón, J.J.; Martínez-Carrasco, C. Seroprevalence of Toxoplasma gondii in outdoor dogs and cats in Bangkok, Thailand. Parasitology 2021, 148, 843-849. [CrossRef]

13. Inpankaew, T.; Pinyopanuwut, N.; Chimnoi, W.; Kengradomkit, C.; Sununta, C.; Zhang, G.; Nishikawa, Y.; Igarashi, I.; Xuan, X.; Jittapalapong, S. Serodiagnosis of Toxoplasma gondii infection in dairy cows in Thailand. Transbound. Emerg. Dis. 2010, 57, 42-45. [CrossRef]

14. Wiengcharoen, J.; Nakthong, C.; Mitchaothai, J.; Udonsom, R.; Sukthana, Y. Toxoplasmosis and neosporosis among beef cattle slaughtered for food in Western Thailand. Southeast Asian J. Trop. Med. Public Health 2012, 43, 1087-1093.

15. Udonsom, R.; Sukthana, Y.; Nishikawa, Y.; Fereig, R.M.; Jirapattharasate, C. Current situation of Neospora ganinum and Toxoplasma gondii infection among beef cattle in Kanchanaburi, Ratchaburi and Nakhon Patom Provinces, Thailand. Thai J. Vet. Med. 2018, 48, 403-409.

16. Saichua, P.; Jumnainsong, A.; Tantrawatpan, C.; Kiatsopit, N.; Kopolrat, K.; Suwannatrai, A.; Sithithaworn, P. Seroprevalence of Toxoplasma gondii in free range chickens (Gallus domesticus) in Khon Kaen province, Thailand. Trop. Biomed. 2017, 34, 419-424. [PubMed]

17. Jittapalapong, S.; Sangvaranond, A.; Pinyopanuwat, N.; Chimnoi, W.; Khachaeram, W.; Koizumi, S.; Maruyama, S. Seroprevalence of Toxoplasma gondii infection in domestic goats in Satun Province, Thailand. Vet. Parasitol. 2005, 127, 17-22. [CrossRef]

18. Udonsom, R.; Supanta, J.; Tanglakmankhong, O.; Ngoenphisutsin, K.; Nishikawa, Y.; Fereig, R.M.; Jirapattharasate, C. Toxoplasma gondii and Neospora caninum prevalence and risk factors on goat farms in Kanchanaburi province, Thailand. Vet. Integr. Sci. 2012, 19, 65-74. [CrossRef]

19. Thiangtum, K.; Nimsuphun, B.; Pinyopanuwat, N.; Chimnoi, W.; Tunwattana, W.; Tongthainan, D.; Jittapalapong, S.; Rukkwamsuk, T.; Maruyama, S. Seroprevalence of Toxoplasma gondii in captive felids in Thailand. Vet. Parasitol. 2006, 136, 351-355. [CrossRef] 
20. Buddhirongawatr, R.; Chaichoun, K.; Tungsudjai, S.; Udonsom, R.; Thompson, A.; Mahittikorn, O.; Dekumyoy, P.; Sukthana, Y. Seroprevalence and phylogenetic analysis of Toxoplasma gondii from domestic Cats, captive wild felids, free-range wild felids and rats in certain regions of Thailand. Thai J. Vet. Med. 2016, 46, 209-218.

21. Dubey, J.P.; Jones, J.L. Toxoplasma gondii infection in humans and animals in the United States. Int. J. Parasitol. 2008, 38, 1257-1278. [CrossRef] [PubMed]

22. Khan, A.H.; Noordin, R. Serological and molecular rapid diagnostic tests for Toxoplasma infection in humans and animals. Eur. J. Clin. Microbiol. Infect. Dis. 2020, 39, 19-30. [CrossRef]

23. Cai, Y.; Wang, Z.; Li, J.; Li, N.; Wei, F.; Liu, Q. Evaluation of an indirect ELISA using recombinant granule antigen GRA7 for serodiagnosis of Toxoplasma gondii infection in cats. J. Parasitol. 2015, 101, 37-40. [CrossRef]

24. Wang, Z.; Ge, W.; Huang, S.Y.; Li, J.; Zhu, X.Q.; Liu, Q. Evaluation of recombinant granule antigens GRA1 and GRA7 for serodiagnosis of Toxoplasma gondii infection in dogs. BMC Vet. Res. 2014, 10, 158. [CrossRef] [PubMed]

25. Abdelbaset, A.E.; Alhasan, H.; Salman, D.; Karram, M.H.; Ellah Rushdi, M.A.; Xuenan, X.; Igarashi, M. Evaluation of recombinant antigens in combination and single formula for diagnosis of feline toxoplasmosis. Exp. Parasitol. 2017, 172, 1-4. [CrossRef]

26. Ferra, B.; Holec-Gasior, L.; Kur, J. Serodiagnosis of Toxoplasma gondii infection in farm animals (horses, swine, and sheep) by enzyme-linked immunosorbent assay using chimeric antigens. Parasitol. Int. 2015, 64, 288-294. [CrossRef] [PubMed]

27. Ferra, B.; Holec-Gąsior, L.; Grąźlewska, W. Toxoplasma gondii recombinant antigens in the serodiagnosis of toxoplasmosis in domestic and farm Animals. Animals 2020, 10, 1245. [CrossRef] [PubMed]

28. Wiengcharoen, J.; Nokkaew, W.; Prasithpon, S.; Prasomtong, P.; Sukthana, Y. Neospora caninum and Toxoplasma gondii antibodies in captive Elephants (Elephaus Maximus Indicus) in Kanchanaburi Province. Thai J. Vet. Med. 2012, 42, $235-240$.

29. Tuntasuvan, D.; Mohkaew, K.; Dubey, J.P. Seroprevalence of Toxoplasma gondii in Elephants (Elephus maximus indicus) in Thailand. Parasitology 2001, 87, 229-230. [CrossRef]

30. Bansiddhi, P.; Brown, J.L.; Thitaram, C. Welfare Assessment and Activities of Captive Elephants in Thailand. Animals 2020, 10, 919. [CrossRef]

31. Shahiduzzaman, M.; Islam, R.; Khatun, M.M.; Batanova, T.A.; Kitoh, K.; Takashima, Y. Toxoplasma gondii seroprevalence in domestic animals and humans in Mymensingh District, Bangladesh. J. Vet. Med. Sci. 2011, 73, 1375-1376. [CrossRef]

32. Matsuo, K.; Kamai, R.; Uetsu, H.; Goto, H.; Takashima, Y.; Nagamune, K. Seroprevalence of Toxoplasma gondii infection in cattle, horses, pigs and chickens in Japan. Parasitol. Int. 2014, 63, 638-639. [CrossRef]

33. Bártová, E.; Lukášová, R.; Vodička, R.; Váhala, J.; Pavlačík, L.; Budíková, M.; Sedlák, K. Epizootological study on Toxoplasma gondii in zoo animals in the Czech Republic. Acta Trop. 2018, 187, 222-228. [CrossRef]

34. Obwaller, A.; Hassl, A.; Picher, O.; Aspock, H. An enzyme-linked immunosorbent assay with whole trophozoites of Toxoplasma gondii from serum-free tissue culture for detection of specific antibodies. Parasitol. Res. 1995, 81, 361-364. [CrossRef]

35. Babaie, J.; Miri, M.; Sadeghiani, G.; Zare, M.; Khalili, G.; Golkar, M. Expression and Single-step Purification of GRA8 Antigen of Toxoplasma gondii in Escherichia coli. Avicenna J. Med. Biotechnol. 2011, 3, 67-77. [PubMed]

36. Jirapattharasate, C.; Udonsom, R.; Prachasuphap, A.; Jongpitisub, K.; Dhepakson, P. Development and evaluation of recombinant GRA8 protein for the serodiagnosis of Toxoplasma gondii infection in goats. BMC Vet. Res. 2021, 17, 27. [CrossRef]

37. Koethe, M.; Pott, S.; Ludewig, M.; Bangoura, B.; Zöller, B.; Daugschies, A.; Tenter, A.M.; Spekker, K.; Bittame, A.; Mercier, C.; et al. Prevalence of specific IgG-antibodies against Toxoplasma gondii in domestic turkeys determined by kinetic ELISA based on recombinant GRA7 and GRA8. Vet. Parasitol. 2011, 180, 179-190. [CrossRef]

38. Song, Y.; Zhao, Y.; Pan, K.; Shen, B.; Fang, R.; Hu, M.; Zhao, J.; Zhou, Y. Characterization and evaluation of a recombinant multiepitope peptide antigen MAG in the serological diagnosis of Toxoplasma gondii infection in pigs. Parasites Vectors 2021, 14, 408. [CrossRef] [PubMed]

39. Cuhadar, S.; Koseoglu, M.; Atay, A.; Dirican, A. The effect of storage time and freeze-thaw cycles on the stability of serum samples. Biochem. Med. 2013, 23, 70-77. [CrossRef]

40. Kempf, J.; Melliger, R.H.; Reusch, C.E.; Kook, P.H. Effects of storage conditions and duration on cobalamin concentration in serum samples from cats and dogs. J. Am. Vet. Med. Assoc. 2018, 252, 1368-1371. [CrossRef] [PubMed]

41. Dard, C.; Bailly, S.; Drouet, T.; Fricker-Hidalgo, H.; Brenier-Pinchart, M.P.; Pelloux, H. Long-term sera storage does not significantly modify the interpretation of toxoplasmosis serologies. J. Microbiol. Methods 2017, 134, 38-45. [CrossRef] [PubMed]

42. Hoornweg, T.E.; Schaftenaar, W.; Maurer, G.; van den Doel, P.B.; Molenaar, F.M.; Chamouard-Galante, A.; Vercammen, F.; Rutten, V.; de Haan, C. Elephant endotheliotropic Herpesvirus is omnipresent in elephants in European zoos and an Asian elephant range country. Viruses 2021, 13, 283. [CrossRef] [PubMed]

43. Paungpin, W.; Wiriyarat, W.; Chaichoun, K.; Tiyanun, E.; Sangkachai, N.; Changsom, D.; Poltep, K.; Ratanakorn, P.; Puthavathana, P. Serosurveillance for pandemic influenza A (H1N1) 2009 virus infection in domestic elephants, Thailand. PLoS ONE 2017, 12, e0186962. [CrossRef] [PubMed] 